\title{
Revisiting Thyroid Hormones in Schizophrenia
}

\author{
Nadine Correia Santos, ${ }^{1,2}$ Patrício Costa, ${ }^{1,2}$ Dina Ruano, ${ }^{1,3}$ \\ António Macedo, ${ }^{4}$ Maria João Soares, ${ }^{4}$ José Valente, ${ }^{4}$ Ana Telma Pereira, ${ }^{4}$ \\ Maria Helena Azevedo, ${ }^{4}$ and Joana Almeida Palha ${ }^{1,2}$ \\ ${ }^{1}$ Life and Health Sciences Research Institute (ICVS), School of Health Sciences, University of Minho, Campus de Gualtar, \\ 4710-057 Braga, Portugal \\ ${ }^{2}$ ICVS-3Bs PT Government Associate Laboratory, Braga, Guimarães, Portugal \\ ${ }^{3}$ Department of Pathology, Leiden University Medical Center, Leiden, The Netherlands \\ ${ }^{4}$ Institute of Medical Psychology, Faculty of Medicine, University of Coimbra, Coimbra, Portugal
}

Correspondence should be addressed to Joana Almeida Palha, japalha@ecsaude.uminho.pt

Received 3 November 2011; Revised 4 January 2012; Accepted 5 January 2012

Academic Editor: Michael Bauer

Copyright (C) 2012 Nadine Correia Santos et al. This is an open access article distributed under the Creative Commons Attribution License, which permits unrestricted use, distribution, and reproduction in any medium, provided the original work is properly cited.

\begin{abstract}
Thyroid hormones are crucial during development and in the adult brain. Of interest, fluctuations in the levels of thyroid hormones at various times during development and throughout life can impact on psychiatric disease manifestation and response to treatment. Here we review research on thyroid function assessment in schizophrenia, relating interrelations between the pituitary-thyroid axis and major neurosignaling systems involved in schizophrenia's pathophysiology. These include the serotonergic, dopaminergic, glutamatergic, and GABAergic networks, as well as myelination and inflammatory processes. The available evidence supports that thyroid hormones deregulation is a common feature in schizophrenia and that the implications of thyroid hormones homeostasis in the fine-tuning of crucial brain networks warrants further research.
\end{abstract}

\section{Introduction}

In 1888 a report by the Committee of the Clinical Society of London explored the association of hypothyroidism with psychosis [1]. Not surprisingly, given the essential role of thyroid hormones for mammalian brain development, the effect of thyroid hormones (THs) in the modulation of affective illness and behavior continues to be an avenue of research in the pathophysiology of mood disorders [2-12]. Complementarily, research has revealed the TH modulation of crucial brain neurotransmitter systems [12-15] including the dopaminergic, serotonergic, glutamatergic, and GABAergic networks $[14,16-20]$. As elaborated on throughout this paper, the misregulation of these pathways, as well as the participation of myelination and of cytokines, is of particular relevance in the schizophrenic brain [18, 21-23].

Schizophrenia is one of the most severe psychiatric disorders with an estimated prevalence of $0.7-1.0 \%$ in the population worldwide. It often runs a chronic and debilitating course, with many patients responding poorly to medi- cation and suffering frequent and disrupting relapses. Furthermore, it is accompanied by a great social cost in terms of productivity loss and treatment-related expenses [21]. Its core features include cognitive impairment, delusions, hallucinations, altered volition and emotional reactivity and disorganized behavior. It is now clear that the heterogeneity and complexity of schizophrenia is both at the clinical and aetiological levels and that this complex disorder arises from the interaction of a range of deviant genetic traits and environmental "insults," which may begin to act in the prenatal period [21]. The clear understanding of schizophrenia's molecular mechanism(s) is elusive, and no biological marker has been identified. In effect, a biomarker may be difficult to find if the disease results from a subtle deregulation in a biological network with impact on mental health and behavior. In this context, modulators of transcriptional activity and their carriers/receptors are good candidates in bridging the genetic and environmental determinants of schizophrenia. Among these are TH [24]. 
Circulating THs, the prohormone thyroxine $\left(\mathrm{T}_{4}\right)$ and the active metabolite 3,5,3' -triiodothyronine $\left(\mathrm{T}_{3}\right)$, are lipophilic molecules carried by plasma or cerebrospinal fluid (CSF) proteins. These molecules exert their function mostly via thyroid receptors that bind $\mathrm{T}_{3}$ with high affinity, acting as ligand-inducible transcription factors that regulate expression of $\mathrm{T}_{3}$-responsive genes. Nonetheless, $\mathrm{TH}$ may also act through fast nongenomic actions [25]. The timing and adequate amount of TH's action is crucial for the normal neurodevelopment and maturation of the central nervous system (CNS) and for proper functioning of the adult brain [6]. Given their described roles, it is not entirely unexpected that a link between TH and psychiatric disease may be considered $[24,26]$. In the adult, TH fluctuations are associated with mood alterations, such that changes in TH levels are common in psychiatric patients across all ages [27-34]. Clinical case reports reveal that hyperthyroid individuals may manifest psychosis and depression [34-38]. Additionally, the prevalence of clinical hypothyroidism in psychiatric patients ranges from $0.5 \%$ to $8 \%[34,38]$. In fact, hypothyroid patients, or those with hypothyroxinemia, display mood impairment, as well as decreased motivation and increased depressive symptoms, such that the prevalence of depressive symptoms is close to $50 \%$ in people with hypothyroidism $[34,38]$. In this regard, studies have evidenced the impact (correlation) of TH fluctuations in depression, including the relation between $\mathrm{TH}$ levels and depressive-state and treatment outcome and/or response time to treatment [39-50]. "Of notice, TH seem important for the mood improvement" ability of antidepressants, since about $50 \%$ of treatmentresistant patients become responsive when $\mathrm{TH}$ are coadministered. In particular, $T_{3}$ administration has been recognized to hasten recovery $[51,52]$, although adjunctive supraphysiological doses of $\mathrm{T}_{4}$ have proven especially efficacious in women with unipolar or bipolar disease and refractory to standard medication [13]. In addition, dementia has been reported in cases of severe hypothyroidism [34,38].

In this paper, data on $\mathrm{TH}$ circulating levels in cohorts of schizophrenic patients will be summarized. Also, we will explore the interplay between $\mathrm{TH}$ and main biological networks implicated in schizophrenia.

\section{Thyroid Hormones and Schizophrenia: Relationship with Neurotransmitter Systems and Neural Networks}

The link between TH and schizophrenia is pertinent [24, 26, 53]. In point of fact, several groups have measured TH levels, and other thyroid-related parameters, in schizophrenic patients (hospitalized and outpatients), reporting on several abnormalities. A compilation of these studies is presented in Table 1. For the collection of the presented reports the PubMed database was searched using key terms such as "psychiatric disease," "schizophrenia," and "thyroid hormones [levels]," and/or designation of each thyroid hormone specifically [total and free thyroxine ( $\mathrm{TT}_{4}$ and $\left.\mathrm{FT}_{4}\right)$ and triiodothyronine $\left(\mathrm{TT}_{3}\right.$ and $\mathrm{FT}_{3}$ ), and thyroid stimulating hormone (TSH)]. Subsequently, for the generation of the final list, the PubMed-generated list was cross-referenced with that derived from the bibliography in articles on schizophrenia and/or psychiatric disease and TH. From our analysis, to date, 15 independent studies of human population cohorts have been published addressing the role of TH in schizophrenic patients, with assessments and/or measurement of TH status $[28,33,54-66]$. It is of mention that prior to the mid-1980s the lack of high-sensitivity assays for measurement of TH, specifically for free TH, was a handicap. Nonetheless, earlier reports already made mention of thyroid function abnormalities in schizophrenic patients and their families, as well as on the resemblance between the psychotic symptoms of people with severe hypo- and hyperthyroidism and those of schizophrenic patients [67-69].

Altogether, from the literature analysis, a dynamic relationship emerged. For example, a connection between Brief Psychiatric Rating Scale (BPRS) values, $\mathrm{TT}_{4}$ and $\mathrm{FT}_{4}$ levels and clinical recovery in male psychiatric patients was reported [58]. Also, a study by Roca and colleagues [60] evidenced that $49 \%$ of psychiatric patients, in their study population, exhibited significant changes in one or more $\mathrm{TH}$ levels, with a significant positive correlation between severity of illness and elevations of TH levels. Furthermore, clinical case reports indicate that hyperthyroid individuals may manifest psychosis [35-37], a characteristic of the positive symptoms observed in schizophrenic patients [21], and that hypothyroid individuals display mood impairment, such as decreased motivation and increased depressive symptoms, a presentation similar to the negative symptoms in schizophrenic individuals [21]. Adding to these, unpublished work from our laboratory indicates that, even within normal range, $\mathrm{FT}_{3}$ levels in Portuguese schizophrenic male and female patients were significantly lower when compared to controls and that $\mathrm{FT}_{4}$ levels were significantly lower in male patients when compared to mentally healthy individuals (data presented in meeting proceedings [70]).

Despite difficult interpretation, methodological limitations, and heterogeneity of patients, including complex history of antipsychotic medication, overall observations indicate that TH level fluctuations may have clinical meaning. Such observations are pertinent given that the interaction between the pituitary-thyroid axis and the dopaminergic, serotonergic, glutamatergic, and GABAergic systems, together with any correlation with myelination and proinflammatory response, are relevant in schizophrenic patients in light of their implications in the etiology of the disease [14, $16-20,22,23,71]$. In the schizophrenia context, each of these neural networks will be next addressed.

2.1. Dopaminergic System. Dopamine was the first neurochemical to be associated with schizophrenia, in part due to the efficacy of antipsychotic drugs that block dopamine D2like receptor in alleviating the hallucinations and delusions of patients (review [19]). Additionally, neuroimaging studies have revealed enhanced activity of the nigrostriatal dopamine system, albeit a hypofunctionality of the mesoprefrontal cortical system, in schizophrenic individuals $[72,73]$.

Thyroid hormones have been shown to regulate the levels of dopamine receptors $[74,75]$ and the activity of 


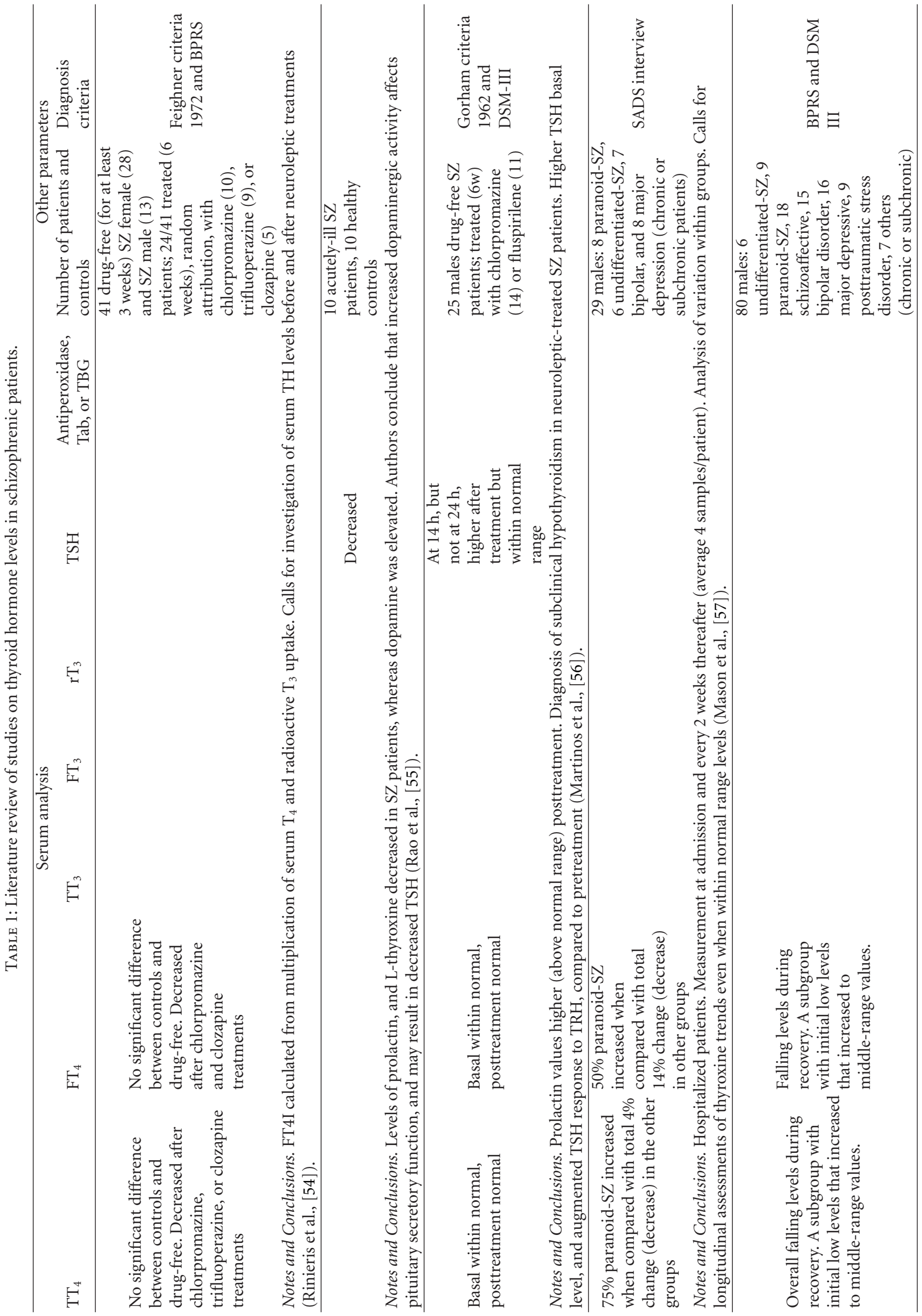




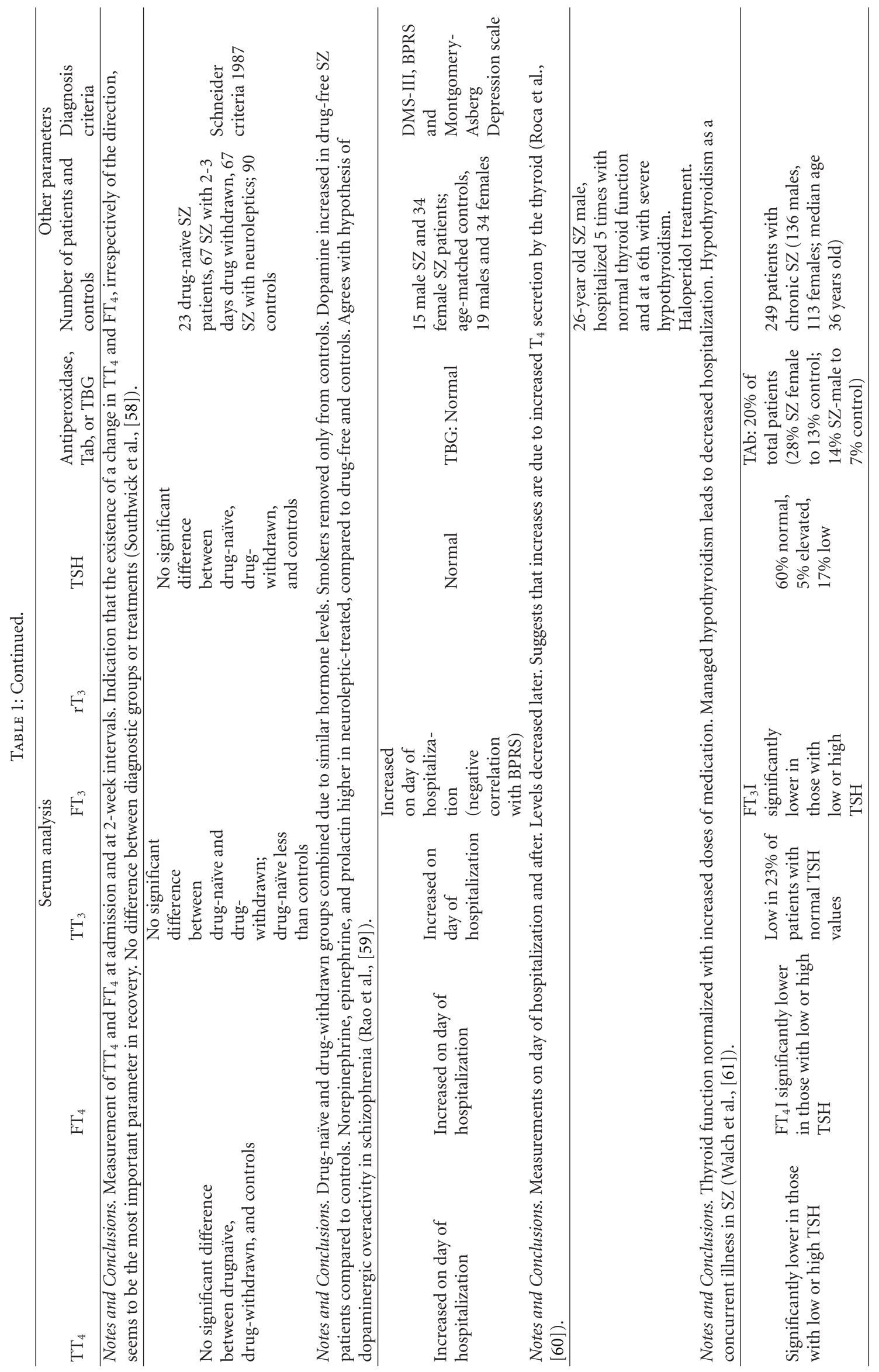




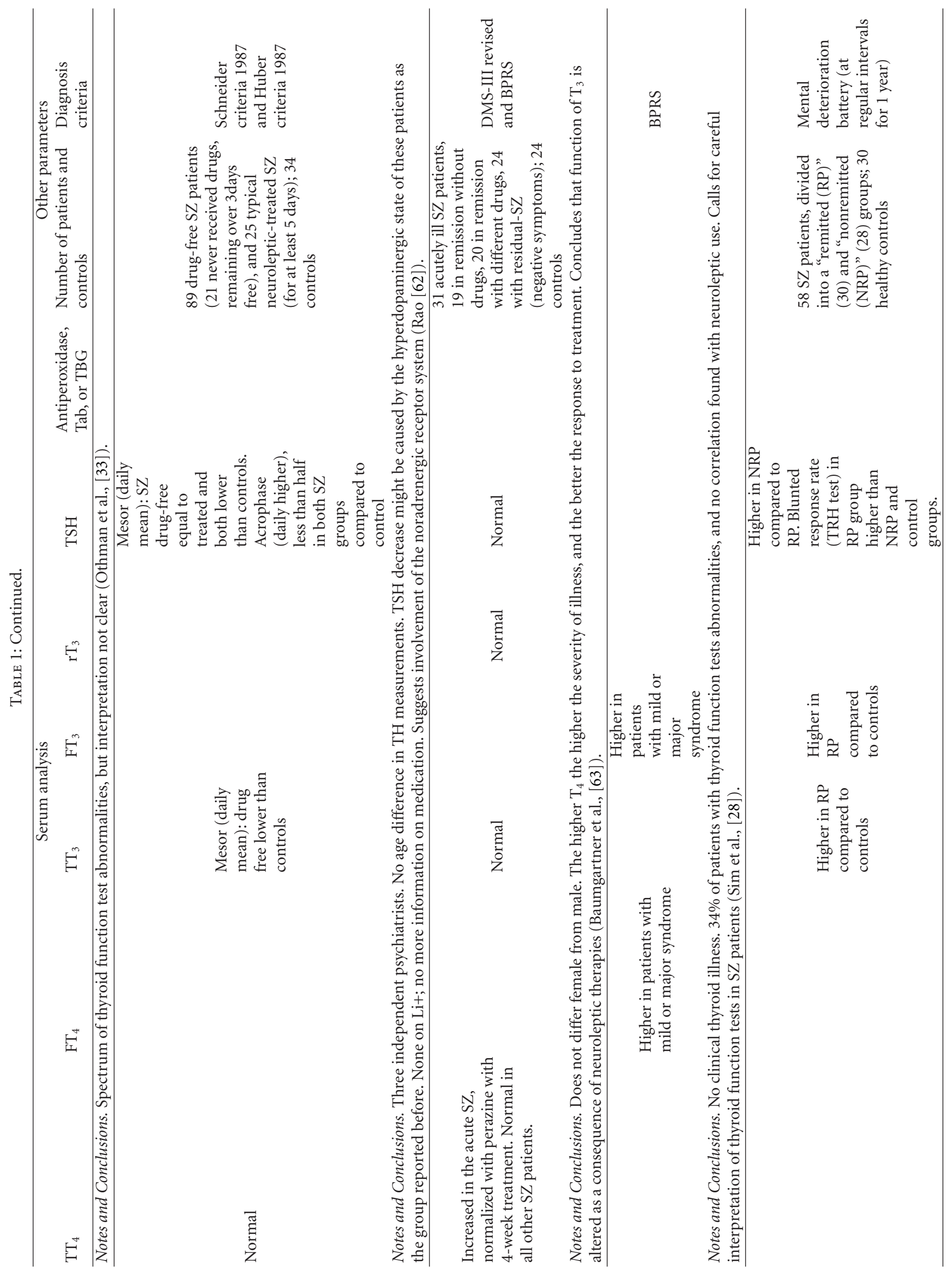




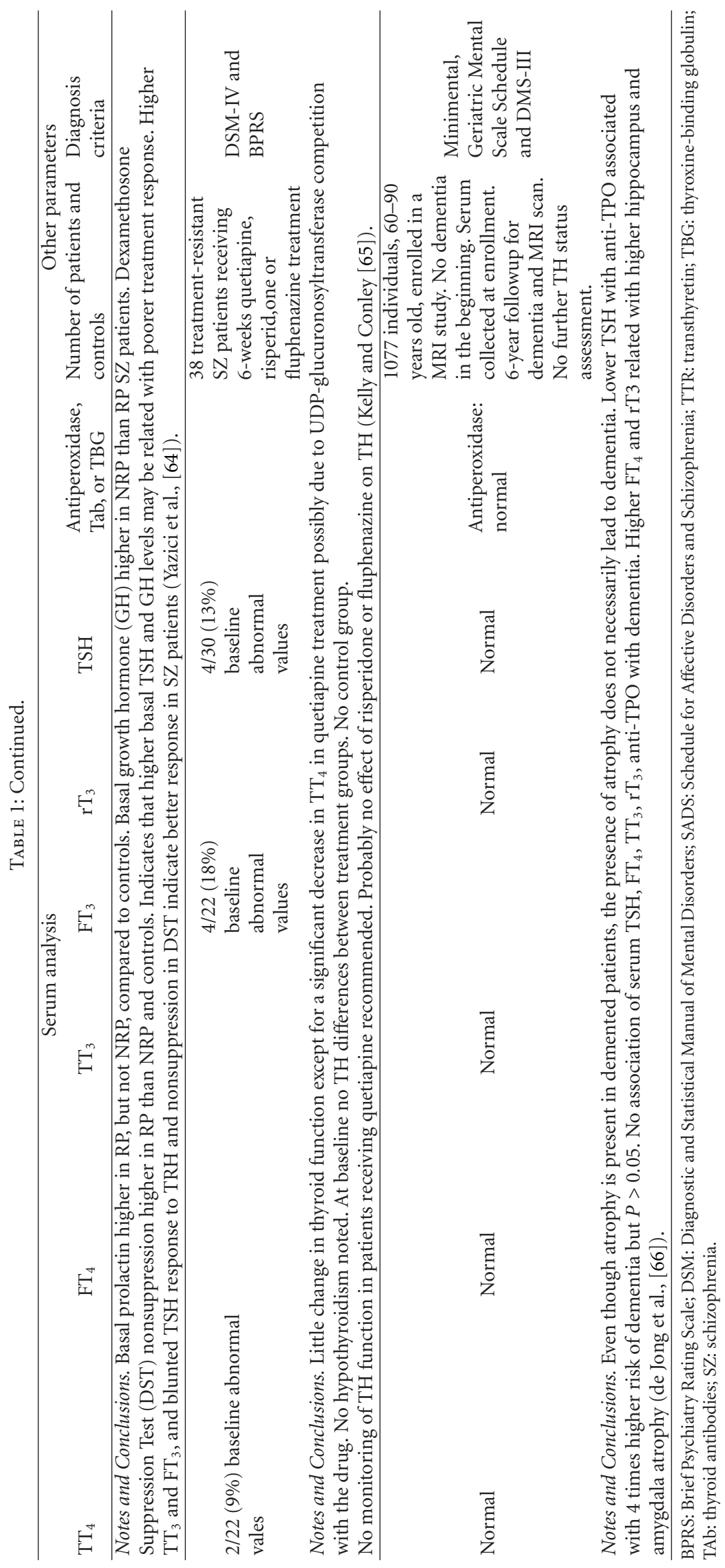


tyrosine hydroxylase [76-78], the rate-limiting enzyme of the cathecolaminergic pathway. Moreover, it has been suggested that dopamine may be inhibitory of TSH secretion [59], as treatment with dopamine blockers lead to increase in TSH level or to subclinical hypothyroidism [79], and that hypothyroidism can lead to increased dopamine receptor sensitivity [74]. In a human study of acutely ill schizophrenic patients, Rao et al. [55] analyzed the interrelation between serum levels of dopamine, prolactin, $\mathrm{TSH}$, and $\mathrm{T}_{4}$. The serum levels of dopamine were found to be elevated in schizophrenic patients, while levels of the other parameters were decreased. The increased dopaminergic activity was hypothesized to affect the pituitary secretory function, and decreased beta-adrenergic activity was inferred as consequence of decreased serum TSH concentration. This is of further interest as $\alpha 1$ - and $\beta$-adrenergic catecholamines are involved in maintaining deiodinase activity, and thus brain thyroid status [80]. As such, type-1 deiodinase impairment may result in a drop in $T_{3}$ levels, with unchanged $T_{4}$, and type 2 or 3 deiodinase impairment may be reflected in decreased $\mathrm{T}_{4}$ metabolization.

2.2. Serotonergic System. Serotonin (5-hydroxytryptamine, $5-\mathrm{HT}$ ) is an essential neurotransmitter. Curiously, it was first thought to have a role in schizophrenia given its similarity to lysergic acid diethylamide (LSD), a compound that competes for and occupies serotonin's receptor sites, resulting in psychotic symptoms [81]. Since then, perhaps the strongest evidence of serotonin's involvement in schizophrenia is the role that its receptors play in the mechanism of atypical antipsychotic drugs which, besides their high receptor selectivity, show a weak direct dopaminergic antagonist effect [82]. According to the current view, serotonergic signaling may have a modulatory influence on central dopamine transmission, which may significantly contribute to the therapeutic effects of atypical antipsychotics [83]. Altogether, observations led to a serotonin hypothesis of schizophrenia. Enhanced serotonergic signaling, especially via serotonin type $2 \mathrm{~A}$ receptors, is thought to be involved in the pathology of schizophrenia specifically during the early phases of psychoses ([84] and review [20]). On the other hand, deficient central 5-HT functions may underlie some of the negative symptoms in schizophrenic patients $[83,85]$.

Establishing a link between the serotonergic system and TH modulation, Strawn et al. [86] measured CSF concentrations of 5-hydroxyindoleacetic acid (5-HIAA) and homovanillic acid (HVA), major metabolites of serotonin and dopamine, as well as plasma concentrations of various THs. The concentration of 5-HIAA was significantly and negatively correlated with plasma TSH and $\mathrm{TT}_{3}$, while that of HVA was significantly and negatively correlated with plasma $\mathrm{TSH}, \mathrm{TT}_{3}$, and $\mathrm{FT}_{3}$. Such findings, indicative of monoaminethyroid interactions, are significant as studies have shown diminished 5-HT activity in hypothyroid patients $[87,88]$ and a negative correlation between TSH and CSF concentrations of 5-HIAA in patients with unipolar depression [89]. Of note, in a separate population of patients diagnosed with major depressive disorder, no correlation was found between TSH and 5-HIAA [90]. Nonetheless, as reviewed by
Bauer et al. [13], most human studies in hypothyroid patients evidence a reduced 5-HT responsiveness, that is, reversible with TH replacement therapy. Furthermore, studies in hypothyroid-state-induced animals showed that 5-HT turnover is increased in the brainstem and that its levels, as well as those of its precursors, are decreased in the cortex/whole brain [91-94]. Also, reports indicate an increase in cortical 5 -HT concentrations and desensitization (no change in density) of autoinhibitory $5-\mathrm{HT}_{1 \mathrm{~A}}$ receptors in the raphe area, resulting in disinhibition of cortical and hippocampal 5-HT release, and in increased cortical $5-\mathrm{HT}_{2}$ receptor sensitivity [95-97]. Altogether, there is evidence that thyroid status impacts the serotonin system in the adult brain and vice versa [13].

2.3. Glutamatergic System. The glutamatergic hypothesis of schizophrenia is based upon the observation that psychotomimetic agents, such as ketamine and phencyclidine, induce neurocognitive deficiencies and psychotic symptoms, similar to those of schizophrenia, through blockage of the neurotransmission at N-methyl-D-aspartate-(NMDA-) type glutamate receptors [98]. Given that the glutamate/NMDA receptors are ubiquitously distributed in the brain, glutamatergic models of schizophrenia predict widespread cortical dysfunction, in particular hypofunctionality of the forebrain glutamate system (review [16, 99]). Furthermore, supporting the model in which reduced NMDA receptor activity may result in schizophrenic-like behavior, animal data have shown that mice expressing only $5 \%$ of normal levels of the NMDAR1 receptor subunit display behavioral abnormalities similar to those observed in pharmacologically induced animal models of schizophrenia [100]. The phenotype can be ameliorated by treatment with antipsychotic drugs (dopaminergic and serotonergic receptors antagonists). Altogether, the literature corroborates a link between the glutamatergicand dopaminergic-based systems, particularly considering that the NMDA receptors are colocated on brain circuits that regulate dopamine release [99].

Mendes-de-Aguiar et al. [15] studied the role of $\mathrm{T}_{3}$ in the CNS, specifically on regulation of glutamate uptake. The team showed an increased neuronal viability against toxicity when neurons were cultured in the presence of $\mathrm{T}_{3}$ treated astrocytes. Altogether, the authors concluded that $\mathrm{T}_{3}$ is capable of regulating extracellular glutamate levels by modulating the astrocytic glutamate transporters and, consequently, by promoting neuronal development and neuroprotection. In another study, male rats were treated with glutamate receptor agonists and antagonists and serum $\mathrm{TH}$ levels were assessed [101]. The results indicated that agonist administration increased TSH concentrations, while antagonists decreased TSH and TH serum levels, indicating that endogenous excitatory amino acids may play a part in the regulation of TH secretion [102]. These studies are in agreement with reports on glutamate and other endogenous excitatory amino acids, such as L-aspartate, $\mathrm{N}$-methyl-D-aspartate, kainate, and amino-hydroxy-5-methyl-4-isoxazole propionate, in their ability to regulate the secretion of anterior pituitary hormones as well as in the neuroendocrine regulation of the hypothalamic-pituitary axis (review [103]). 
2.4. GABAergic System. The role for the GABA ( $\delta$-aminobutyric acid)-ergic system in the pathogenesis of schizophrenia derives mostly from neuropathologic studies [104]. Specifically, the chandelier neurons, a subtype of GABA interneurons, have decreased immunostaining for the GABA transporter, possibly related to decreased BDNF signaling or NMDA receptor hypofunction. Furthermore, upregulation of the postsynaptic GABA-A receptors, together with reduction of both glutamic acid decarboxylase (GAD) 67 and reelin (a protein that colocalizes with GABAergic interneurons), was described in schizophrenic patients [105]. GAD67 and reelin are involved in the glutamate conversion to GABA and in synaptic plasticity and/or neuromigration.

The possibility that TH affects the GABAergic system was first putforward in the 1960s and since then multiple studies have examined various aspects of this relationship, altogether suggesting that some human nervous disorders involving GABAergic systems are related to thyroid dysfunction. Overall, as expertly reviewed by Wiens and Trudeau [14], the effect of $\mathrm{TH}$ on the GABAergic system can take place at multiple levels, including circuit formation, enzymes involved in synthesis and metabolism of GABA and glutamate, GABA release and reuptake, and GABA receptors. For example, in rat models, thyroidal status has been shown to influence the development of inhibitory cortical GABAergic circuits [106]. Also, neonatal hypothyroidism was evidenced to result in decreased GAD activity in various brain regions of the neonate brain [107, 108], although not in the adult brain. In addition, $\mathrm{T}_{3}$ administration was shown to accelerate the developmental increase in GAD activity in both in vivo and in vitro models $[109,110]$. Furthermore, other studies revealed lower activity of two other enzymes in GABA metabolism, GABA aminotransferase and succinic semialdehyde dehydrogenase, in hypothyroid animals [111], and that $\mathrm{T}_{3}$ replacement restored activity back to control levels [112]. At the GABA concentration level, neonatal rats rendered hypothyroid have reduced whole brain glutamate and GABA concentrations, from within 2 hours of birth to postnatal day 30 [113]; interestingly, levels were not found to be increased in animals rendered hyperthyroid [114]. In contrast, whole glutamate and GABA levels were found elevated in hypothyroid animals [115] (rendered hypothyroid when adults) and, in accordance, with the increase GAD activity also noted. These observations point for the possible diverse influence of TH depending on the developmental stage. Data for animals rendered hyperthyroid are discordant between studies. Overall, evidence continues to indicate a correlation, although a positive correlation between TH levels and GABAergic function in the developing brain and a negative correlation in adult animals is not always a consistent finding [14]. Adding to these observations, studies indicate that TH affects GABA release and reuptake. For example, in in vitro preparations of synaptosomes, from adult rat cerebral cortex, low concentration of $\mathrm{T}_{3}$, but not of $\mathrm{T}_{4}$ or $\mathrm{rT}_{3}$, increased depolarization-induced GABA release by a direct nongenomic mechanism [116]. At the GABA receptor level, studies indicate that $\mathrm{TH}$ have direct nongenomic effects on the $\mathrm{GABA}_{\mathrm{A}}$ receptor complex, specifically that, in the presence of GABA, $\mathrm{T}_{3}$ inhibits GABA-stimulated $\mathrm{Cl}^{-}$currents in rat forebrain membranes and in its absence it induces the $\mathrm{Cl}^{-}$ current $[117,118]$. On the other hand, GABA can affect TH function; GABA can inhibit TSH-stimulated TH release from the thyroid gland and affect TSH secretion from the pituitary.

On the role of adequate functioning of the maternal thyroid gland in offspring thyroid status development, the report by Ahmed et al. [119], on hypo-/hyperthyroidism animal models in dams, is especially noteworthy regarding the TH-GABAergic system interplay. The study revealed that maternal hypothyroidism induced decreases in both monoamine levels and in acetylcholinesterase activity and increases in the GABA content of the offspring. This was accompanied by suppression of $\mathrm{Na}^{+}, \mathrm{K}^{+}$-ATPase, $\mathrm{Ca}^{2+}$-ATPase, and $\mathrm{Mg}^{2+}$ ATPase activity in different brain regions. On the other hand, maternal hyperthyroidism produced reverse effects. The authors concluded that maternal hypothyroidism and hyperthyroidism might induce inhibitory and stimulatory effects, respectively, on the excitability and synaptic neurotransmissions in the progeny's brain [119].

2.5. Myelination and Cytokines. The TH involvement in the regulation of myelination and/or oligodendrocytes' functionality, central processes in the modulation of neural networks, is of interest in schizophrenia, where involvement of white matter has been implicated [22, 71, 120-123].

Associations between $\mathrm{TH}$ levels and myelination have been reported. Hypothyroidism is associated with delayed myelination in several brain regions [124, 125]. Furthermore, myelin-related genes, shown to be downregulated in postmortem schizophrenic brain, including cyclic nucleotide phosphodiesterase, myelin-associated glycoprotein, transferring, and v-erb-b2 erythroblastic leukemia viral oncogene homolog 3 [122], are regulated by TH. Also, changes observed in the identified cell cycle genes, from microarray analysis of schizophrenic patients [123], are particularly interesting given that two genes, cyclin D1 and cyclin-dependent kinase inhibitor 1C (P57), central to oligodendrocyte differentiation, have been shown to be among the early regulated cell cycle genes after exposure to TH, a "cue" essential to trigger oligodendrocyte differentiation $[126,127]$.

Myelin abnormalities in the neurological/psychiatricdiseased brain are often presented with an inflammatory component. In schizophrenia, evidence from clinical data supports a potential pathogenic role of elevated cytokine expression. Both childhood and adult schizophrenia are characterized by elevated expression of IL-1, IL-6, and TNF$\alpha$ in the CSF, along with altered cytokine or cytokine receptor expression $[23,128]$. While many cytokines may be virtually undetectable in a healthy noninflamed system, their induction (abnormal or in a response to an inflammatory trigger) in immune and glial cells, such as astrocytes and microglia, may play a significant role in the deregulation of neural cell homeostasis, with vast consequences at the level of oligodendrocyte function and myelination (review [71]). In this line, it is relevant to mention that whereas THs play an important role in the regulation of deiodinases activity under normal metabolic conditions, other regulating mechanisms might be involved in $\mathrm{TH}$ metabolism during pathophysiological conditions, which may overlap with those known to be 
relevant for the development of schizophrenia. During these conditions, a state of altered TH metabolism can occur [nonthyroidal illness (NTI)], which is characterized by a fall of serum $\mathrm{T}_{3}[129,130]$, due to decreased extrathyroidal conversion of $\mathrm{T}_{4}$ into $\mathrm{T}_{3}$ by type 1 deiodinase, without an increase in serum TSH $[131,132]$. In these studies, TR $\beta 1$ has been found to be downregulated (in an animal model of NTI), and type 3 deiodinase activity shown to be upregulated in liver and skeletal muscle of critically ill patients. Correspondingly, what renders these observations of particular interest, in the schizophrenia-TH-inflammation interrelation, is that in sites of local inflammation, induced in animal models by sitedirected bacterial endotoxin (lipopolysaccharide) administration, deiodinase type 3 activity in inflammatory cells is strongly induced, suggesting enhanced local degradation of $\mathrm{T}_{3}[132]$.

2.6. Thyroid Hormones as Neurotransmitters. The role of TH in the pathophysiology of schizophrenia is more so noteworthy when considering the possible function of $\mathrm{TH}$ as neurotransmitters. The breakthrough hypothesis of a neurotransmitter role for $\mathrm{T}_{3}$ was put forward in the endocrinology field in the 1970s by Dratman and collaborators [133], based on the colocalization of $\mathrm{TH}$ with the noradrenergic system [134]. Given the vast roles of $T_{3}$ in the brain, this is hardly unexpected. Among others, $\mathrm{T}_{3}$ promotes differentiation in astrocytes, mediates cerebellar astrocyte and neuronal proliferation, and participates in the organization of extracellular matrix molecules via astrocytes $[15,135]$. Recently, Scanlan and team (review [136]) have explored a similar neurotransmitter function for 3-iodothyronamine (T(1)AM), a molecule proposed to result from a unique biosynthetic deiodination pathway starting from the decarboxylation products of either $\mathrm{T}_{4}$ or $\mathrm{rT}_{3}$. The hormone $\mathrm{T}_{3}$ is reported to accumulate in nerve endings reaching high concentrations in the synaptosome $[137,138]$ and being released from it in a $\mathrm{Ca}^{2+}$-dependent mechanism [139]. In in vitro studies T1AM has been found to block the transporters for the amines/neurotransmitters dopamine, norepinephrine, and serotonin. Interestingly, T1AM binds with high affinity to the trace-amine-associated receptor (TAAR) $[136,140]$, a class of G-protein-coupled receptors, and genetic linkage studies have shown a significant association between the TAAR gene and susceptibility to schizophrenia [141].

\section{Thyroid Hormones and Schizophrenia: Human Studies Considerations}

Thyroid hormones are widely distributed in the brain, with a multitude of effects on the CNS including a putative effect in the pathogenesis of psychiatric disorders. Indicating this interrelation, the successful treatment of affective disorders often includes the coadministration of TH. Despite these observations, the molecular action(s) that may underlie the mood-modulating properties of $\mathrm{TH}$ in the adult brain has only fairly recently become of greater interest. As such, when reporting on this type of analysis, three main aspects are of essence for the neuropsychiatric community to incorporate and/or consider in current and future studies: (i) the effect of antipsychotic medication, (ii) determination of CSF levels of $\mathrm{TH}$, and (iii) the introduction of longitudinal studies of prenatal, neonatal, and/or childhood TH status, related to propensity to develop schizophrenia at the adult age, particularly in at-risk offspring (e.g., familial history of schizophrenia), as well as familial TH level correlations. These will next be summarily discussed.

\subsection{Effect of Antipsychotic Medication on Thyroid Hormone} Status. The literature reports on the effect of neuroleptic medication on deiodinases activities, as well as on the N-glucuronidation of $\mathrm{TH}$, and by consequence on $\mathrm{TH}$ levels. Namely, the commonly used antipsychotic haloperidol can enhance type 2 deiodinase, while clozapine decreases type 2 but increases type 3 deiodinase activity in several brain regions [142]. In addition, some antipsychotics, such as clozapine, are piperazine-containing drugs that undergo N-glucuronidation. Given that the enzyme UDP-glucuronosyltransferase is responsible for the glucuronidation of $\mathrm{TH}$ and of certain psychotropic medications [143], a competitive mechanism may be conducive to TH level changes [65]. Finally, it may also be worthy of consideration that, even in cases where no change in circulating levels of TH is observed, deregulated deiodinase activity may affect the spatiotemporal distribution and local regulation of TH $[144,145]$.

3.2. Serum and CSF Thyroid Hormone Level Assessments. The measurement of TH levels in CSF samples would be more likely to represent TH brain homeostasis. Not only would this type of analysis add to ones already done to identify schizophrenia disease markers (e.g., [146] and review [147]), but it would also fill in a gap regarding the measurement of TH levels in the CSF of schizophrenic patients as such study is lacking in the field. This could be done in a manner similar to a study in an Alzheimer's disease population, which revealed $\mathrm{rT}_{3}$ level alterations in the CSF that were not reflected in the sera samples [148].

\subsection{Familial, PreNatal, Neonate, and Early Childhood Thyroid} Status. During development TH play a crucial role in CNS development, including in cerebral cytoarchitecture, neural growth, and synaptogenesis [149-151]. Consequently, it follows that the thyroid status and timing during development, including neonatal, has a significant impact on behavior, locomotor ability, speech, and cognition [2-8, 152]. Furthermore, given that the fetus relies on the mother for the adequate supply for $\mathrm{TH}$, it is relevant to consider maternal thyroid status during pregnancy; for example, maternal hypothyroxinemia leads to decreased $\mathrm{T}_{4}$ availability for the fetal brain, that is, associated with neuropsychological impairments of the child [153]. Neurodevelopment can be restored to within the normal range upon TH supplementation in case of neonatal hypothyroidism [154], although subtle abnormalities remain in these children. Such observations are further correlated with animal work findings that indicate how TH status, even prenatally, may impact on neuronal excitability and synaptic transmission within the CNS [119]. Altogether, TH status seems relevant in the pre- and postnatal periods, and there are critical periods during which 
different parts of the brain and/or aspects of the CNS development are sensitive to TH supply [155]. Thus, to further understand the impact of $\mathrm{TH}$ on behavior, it would be of interest not only to investigate $\mathrm{TH}$ status in adulthood in mood and cognitive disorders, but also how alterations in the hormonal milieu during development might impact on adult behavior (as has been recently shown to be case for other hormones, such as glucocorticoids [156, 157]). In this regard, it would be further interesting to broaden thyroid assessment studies to include mentally healthy siblings of schizophrenia patients.

\section{Conclusions}

Thyroid hormone assessment in schizophrenic patients presents a particular challenge. Often, the heterogeneity of patients, including many with a complex history of antipsychotic medication, renders impossible a "clean" TH basal determination in disease state. Deregulations of the pituitary-TH axis continue to be of interest given the interaction between the pituitary-thyroid axis and the dopaminergic, serotonergic, glutamatergic, and GABAergic systems, together with relationships with myelination and proinflammatory response, which are strongly implicated in schizophrenia. The fine-tuning of these networks and their precise implication on disease etiology certainly warrants further investigation.

\section{Acknowledgments}

The present work was supported by Grant POCI/SAUESP/58757/2004 from the Portuguese Science Foundation (FCT/FEDER). NCS was supported by the fellowship SFRH/ BPD/51057/2010 by FCT.

\section{References}

[1] L. Doyle, "Myxoedema: some early reports and contributions by British authors, 1873-1898," Journal of the Royal Society of Medicine, vol. 84, no. 2, pp. 103-106, 1991.

[2] R. T. Zoeller and J. Rovet, "Timing of thyroid hormone action in the developing brain: clinical observations and experimental findings," Journal of Neuroendocrinology, vol. 16, no. 10, pp. 809-818, 2004.

[3] J. Bernal, "Thyroid hormone receptors in brain development and function," Nature Clinical Practice Endocrinology and Metabolism, vol. 3, no. 3, pp. 249-259, 2007.

[4] G. M. de Escobar, M. J. Obregón, and F. E. del Rey, "Role of thyroid hormone during early brain development," European Journal of Endocrinology, vol. 151, no. 3, pp. U25-U37, 2004.

[5] G. W. Anderson, "Thyroid hormone and cerebellar development," Cerebellum, vol. 7, no. 1, pp. 60-74, 2008.

[6] J. Bernal, "Thyroid Hormones and Brain Development," Vitamins and Hormones, vol. 71, pp. 95-122, 2005.

[7] J. Nunez, F. S. Celi, L. Ng, and D. Forrest, "Multigenic control of thyroid hormone functions in the nervous system," Molecular and Cellular Endocrinology, vol. 287, no. 1-2, pp. 1-12, 2008.
[8] S. Chan and M. D. Kilby, "Thyroid hormone and central nervous system development," Journal of Endocrinology, vol. 165, no. 1, pp. 1-8, 2000.

[9] S. P. Porterfield and C. E. Hendrich, "The role of thyroid hormones in prenatal and neonatal neurological development Current perspectives," Endocrine Reviews, vol. 14, no. 1, pp. 94-106, 1993.

[10] G. M. de Escobar, M. J. Obregón, and F. E. del Rey, "Maternal thyroid hormones early in prenancy and fetal brain development," Best Practice and Research, vol. 18, no. 2, pp. 225-248, 2004.

[11] G. R. De Long, J. B. Stanbury, and R. Fierro-Benitez, "Neurological signs in congenital iodine-deficiency disorder (endemic cretinism)," Developmental Medicine and Child Neurology, vol. 27, no. 3, pp. 317-324, 1985.

[12] O. M. Ahmed, A. W. El-Gareib, A. M. El-bakry, S. M. Abd El-Tawab, and R. G. Ahmed, "Thyroid hormones states and brain development interactions," International Journal of Developmental Neuroscience, vol. 26, no. 2, pp. 147-209, 2008.

[13] M. Bauer, A. Heinz, and P. C. Whybrow, "Thyroid hormones, serotonin and mood: of synergy and significance in the adult brain," Molecular Psychiatry, vol. 7, no. 2, pp. 140-156, 2002.

[14] S. C. Wiens and V. L. Trudeau, "Thyroid hormone and $\gamma$ aminobutyric acid (GABA) interactions in neuroendocrine systems," Comparative Biochemistry and Physiology, vol. 144, no. 3, pp. 332-344, 2006.

[15] C. B. Mendes-de-Aguiar, R. Alchini, H. Decker, M. AlvarezSilva, C. I. Tasca, and A. G. Trentin, "Thyroid hormone increases astrocytic glutamate uptake and protects astrocytes and neurons against glutamate toxicity," Journal of Neuroscience Research, vol. 86, no. 14, pp. 3117-3125, 2008.

[16] D. A. Collier and T. Li, "The genetics of schizophrenia: glutamate not dopamine?" European Journal of Pharmacology, vol. 480, no. 1-3, pp. 177-184, 2003.

[17] S. Kapur, "Psychosis as a state of aberrant salience: a framework linking biology, phenomenology, and pharmacology in schizophrenia," American Journal of Psychiatry, vol. 160, no. 1, pp. 13-23, 2003.

[18] A. Carlsson, "The neurochemical circuitry of schizophrenia," Pharmacopsychiatry, vol. 39, no. 1, pp. S10-S14, 2006.

[19] S. H. Snyder, "Dopamine receptor excess and mouse madness," Neuron, vol. 49, no. 4, pp. 484-485, 2006.

[20] M. A. Geyer and F. X. Vollenweider, "Serotonin research: contributions to understanding psychoses," Trends in pharmacological sciences, vol. 29, no. 9, pp. 445-453, 2008.

[21] A. W. MacDonald and S. C. Schulz, "What we know: findings that every theory of Schizophrenia should explain," Schizophrenia Bulletin, vol. 35, no. 3, pp. 493-508, 2009.

[22] K. L. Davis, D. G. Stewart, J. I. Friedman et al., "White matter changes in schizophrenia evidence for myelin-related dysfunction," Archives of General Psychiatry, vol. 60, no. 5, pp. 443-456, 2003.

[23] S. Potvin, E. Stip, A. A. Sepehry, A. Gendron, R. Bah, and E. Kouassi, "Inflammatory cytokine alterations in schizophrenia: a systematic quantitative review," Biological Psychiatry, vol. 63, no. 8, pp. 801-808, 2008.

[24] J. A. Palha and A. B. Goodman, "Thyroid hormones and retinoids: a possible link between genes and environment in schizophrenia," Brain Research Reviews, vol. 51, no. 1, pp. 6171, 2006.

[25] S. Y. Cheng, J. L. Leonard, and P. J. Davis, "Molecular aspects of thyroid hormone actions," Endocrine Reviews, vol. 31, no. 2, pp. 139-170, 2010. 
[26] R. Bunevicius, "Thyroid disorders in mental patients," Current Opinion in Psychiatry, vol. 22, no. 4, pp. 391-395, 2009.

[27] F. S. Valdivieso, C. Kripper, J. A. Ivelic, C. Fardella, S. Gloger, and D. Quiroz, "High prevalence of thyroid dysfunction among psychiatric inpatients," Revista Medica de Chile, vol. 134, no. 5, pp. 623-628, 2006.

[28] K. Sim, S. A. Chong, Y. H. Chan, and W. M. Lum, “Thyroid dysfunction in chronic schizophrenia within a state psychiatric hospital," Annals of the Academy of Medicine Singapore, vol. 31, no. 5, pp. 641-644, 2002.

[29] J. Valle, J. L. Ayuso-Gutierrez, A. Abril, and J. L. AyusoMateos, "Evaluation of thyroid function in lithium-naive bipolar patients," European Psychiatry, vol. 14, no. 6, pp. 341345, 1999.

[30] G. P. Placidi, M. Boldrini, A. Patronelli et al., "Prevalence of psychiatric disorders in thyroid diseased patients," Neuropsychobiology, vol. 38, no. 4, pp. 222-225, 1998.

[31] M. L. Rao, S. Ruhrmann, B. Retey et al., "Low plasma thyroid indices of depressed patients are attenuated by antidepressant drugs and influence treatment outcome," Pharmacopsychiatry, vol. 29, no. 5, pp. 180-186, 1996.

[32] I. Hickie, B. Bennett, P. Mitchell, K. Wilhelm, and W. Orlay, "Clinical and subclinical hypothyroidism in patients with chronic and treatment-resistant depression," Australian and New Zealand Journal of Psychiatry, vol. 30, no. 2, pp. 246252, 1996.

[33] S. S. Othman, K. A. Kadir, J. Hassan, G. K. Hong, B. B. Singh, and N. Raman, "High prevalence of thyroid function test abnormalities in chronic schizophrenia," Australian and New Zealand Journal of Psychiatry, vol. 28, no. 4, pp. 620-624, 1994.

[34] S. Sabeen, C. Chou, and S. Holroyd, "Abnormal thyroid stimulating hormone (TSH) in psychiatric long-term care patients," Archives of Gerontology and Geriatrics, vol. 51, no. 1, pp. 6-8, 2010.

[35] G. Marian, E. A. Nica, B. E. Ionescu, and D. Ghinea, "Hyperthyroidism-cause of depression and psychosis: a case report," Journal of medicine and life, vol. 2, no. 4, pp. 440-442, 2009.

[36] T. Snabboon, A. Khemkha, C. Chaiyaumporn, D. Lalitanantpong, and V. Sridama, "Psychosis as the first presentation of hyperthyroidism," Internal and Emergency Medicine, vol. 4, no. 4, pp. 359-360, 2009.

[37] S. Benvenga, D. Lapa, and F. Trimarchi, "Don't forget the thyroid in the etiology of psychoses," American Journal of Medicine, vol. 115, no. 2, pp. 159-160, 2003.

[38] S. C. Bahls and G. A. de Carvalho, "The relation between thyroid function and depression: a review," Revista Brasileira de Psiquiatria, vol. 26, no. 1, pp. 41-49, 2004.

[39] K. N. Fountoulakis, S. Kantartzis, M. Siamouli et al., "Peripheral thyroid dysfunction in depression," World Journal of Biological Psychiatry, vol. 7, no. 3, pp. 131-137, 2006.

[40] G. Abraham, R. Milev, and J. Stuart Lawson, "T3 augmentation of SSRI resistant depression," Journal of Affective Disorders, vol. 91, no. 2-3, pp. 211-215, 2006.

[41] O. Abulseoud, N. Sane, A. Cozzolino et al., "Free T4 index and clinical outcome in patients with depression," Journal of Affective Disorders, vol. 100, no. 1-3, pp. 271-277, 2007.

[42] J. P. Brouwer, B. C. Appelhof, W. J. G. Hoogendijk et al., "Thyroid and adrenal axis in major depression: a controlled study in outpatients," European Journal of Endocrinology, vol. 152, no. 2, pp. 185-191, 2005.
[43] V. B. Chueire, J. H. Romaldini, and L. S. Ward, "Subclinical hypothyroidism increases the risk for depression in the elderly," Archives of Gerontology and Geriatrics, vol. 44, no. 1, pp. 21-28, 2007.

[44] T. Gunnarsson, S. Sjöberg, M. Eriksson, and C. Nordin, "Depressive symptoms in hypothyroid disorder with some observations on biochemical correlates," Neuropsychobiology, vol. 43, no. 2, pp. 70-74, 2001.

[45] P. F. Sullivan, D. A. Wilson, R. T. Mulder, and P. R. Joyce, "The hypothalamic-pituitary-thyroid axis in major depression," Acta Psychiatrica Scandinavica, vol. 95, no. 5, pp. 370-378, 1997.

[46] C. Kirkegaard and J. Faber, "Free thyroxine and 3,3',5'triiodothyronine levels in cerebrospinal fluid in patients with endogenous depression," Acta Endocrinologica, vol. 124, no. 2, pp. 166-172, 1991.

[47] W. M. Wiersinga, "Do we need still more trials on T4 and T3 combination therapy in hypothyroidism?" European Journal of Endocrinology, vol. 161, no. 6, pp. 955-959, 2009.

[48] C. U. Pae, L. Mandelli, C. Han et al., "Thyroid hormones affect recovery from depression during antidepressant treatment," Psychiatry and Clinical Neurosciences, vol. 63, no. 3, pp. 305-313, 2009.

[49] S. K. Rack and E. H. Makela, "Hypothyroidism and depression: a therapeutic challenge," Annals of Pharmacotherapy, vol. 34, no. 10, pp. 1142-1145, 2000.

[50] C. Kirkegaard and J. Faber, "The role of thyroid hormones in depression," European Journal of Endocrinology, vol. 138, no. 1, pp. 1-9, 1998.

[51] R. Aronson, H. J. Offman, R. T. Joffe, and C. David Naylor, "Triiodothyronine augmentation in the treatment of refractory depression: a meta-analysis," Archives of General Psychiatry, vol. 53, no. 9, pp. 842-848, 1996.

[52] L. L. Altshuler, M. Bauer, M. A. Frye et al., "Does thyroid supplementation accelerate tricyclic antidepressant response? A review and meta-analysis of the literature," American Journal of Psychiatry, vol. 158, no. 10, pp. 1617-1622, 2001.

[53] L. Mebis and G. van den Berghe, "The hypothalamuspituitary-thyroid axis in critical illness," Netherlands Journal of Medicine, vol. 67, no. 10, pp. 332-340, 2009.

[54] P. Rinieris, G. N. Christodoulou, and A. Souvatzoglou, "Freethyroxine index in schizophrenic patients before and after neuroleptic treatment," Neuropsychobiology, vol. 6, no. 1, pp. 29-33, 1980.

[55] M. L. Rao, G. Gross, and G. Huber, "Altered interrelationship of dopamine, prolactin, thyrotropin and thyroid hormone in schizophrenic patients," European Archives of Psychiatry and Neurological Sciences, vol. 234, no. 1, pp. 8-12, 1984.

[56] A. Martinos, P. Rinieris, and A. Souvatzoglou, "Effects of six weeks' neuroleptic treatment on the pituitary-thyroid axis in schizophrenic patients," Neuropsychobiology, vol. 16, no. 2-3, pp. 72-77, 1986.

[57] J. W. Mason, J. L. Kennedy, T. R. Kosten, and E. L. Giller, "Serum thyroxine levels in schizophrenic and affective disorder diagnostic subgroups," The Journal of Nervous and Mental Disease, vol. 177, no. 6, pp. 351-358, 1989.

[58] S. Southwick, J. W. Mason, E. L. Giller, and T. R. Kosten, "Serum thyroxine change and clinical recovery in psychiatric inpatients," Biological Psychiatry, vol. 25, no. 1, pp. 67-74, 1989.

[59] M. L. Rao, G. Gross, B. Strebel, P. Braunig, G. Huber, and J. Klosterkotter, "Serum amino acids, central monoamines, and hormones in drug-naive, drug-free, and neuroleptic-treated 
schizophrenic patients and healthy subjects," Psychiatry Research, vol. 34, no. 3, pp. 243-257, 1990.

[60] R. P. Roca, M. R. Blackman, M. B. Ackerley, S. M. Harman, and R. I. Gregerman, "Thyroid hormone elevations during acute psychiatric illness: relationship to severity and distinction from hyperthyroidism," Endocrine Research, vol. 16, no. 4, pp. 415-447, 1990.

[61] T. J. Walch, "Enhancing compliance in schizophrenic patients by weekly dosing with levothyroxine sodium," Journal of Clinical Psychiatry, vol. 55, no. 12, p. 543, 1994.

[62] M. L. Rao, "Circadian rhythm of vital signs, norepinephrine, epinephrine, thyroid hormones, and cortisol in schizophrenia," Psychiatry Research, vol. 57, no. 1, pp. 21-39, 1995.

[63] A. Baumgartner, A. Pietzcker, and W. Gaebel, "The hypothalamic-pituitary-thyroid axis in patients with schizophrenia," Schizophrenia Research, vol. 44, no. 3, pp. 233-243, 2000.

[64] K. Yazici, A. E. Yazici, and B. Taneli, "Different neuroendocrine profiles of remitted and nonremitted schizophrenic patients," Progress in Neuro-Psychopharmacology and Biological Psychiatry, vol. 26, no. 3, pp. 579-584, 2002.

[65] D. L. Kelly and R. R. Conley, "Thyroid function in treatmentresistant schizophrenia patients treated with quetiapine, risperidone, or fluphenazine," The Journal of clinical psychiatry, vol. 66, no. 1, pp. 80-84, 2005.

[66] F. J. De Jong, T. den Heijer, T. J. Visser et al., "Thyroid hormones, dementia, and atrophy of the medial temporal lobe," Journal of Clinical Endocrinology and Metabolism, vol. 91, no. 7, pp. 2569-2573, 2006.

[67] R. Asher, "Myxoedematous madness," British Medical Journal, vol. 2, no. 4627, pp. 555-562, 1949.

[68] B. Bursten, "Psychoses associated with thyrotoxicosis," Archives of General Psychiatry, vol. 4, pp. 267-273, 1961.

[69] N. S. Kline, J. Blair, T. B. Cooper, A. H. Esser, E. Hackett, and P. Vestergaard, "A controlled sevn year study of endocrine and other indices in drug treated chronic schizophrenics," Acta Psychiatrica Scandinavica, Supplement, vol. 206, pp. 7-75, 1968.

[70] J. A. Palha, D. Ruano, N. C. Santos et al., Circulating Thyroid Hormones in Schizophrenia, Society for Neurosciences, San Diego, Calif, USA, 2010.

[71] T. Schmitz and L. J. Chew, "Cytokines and myelination in the central nervous system," The Scientific World Journal, vol. 8, pp. 1119-1147, 2008.

[72] M. Laruelle, A. Abi-Dargham, R. Gil, L. Kegeles, and R. Innis, "Increased dopamine transmission in schizophrenia: relationship to illness phases," Biological Psychiatry, vol. 46, no. 1, pp. 56-72, 1999.

[73] M. Laruelle, A. Abi-Dargham, C. H. van Dyck et al., "Single photon emission computerized tomography imaging of amphetamine-induced dopamine release in drug-free schizophrenic subjects," Proceedings of the National Academy of Sciences of the United States of America, vol. 93, no. 17, pp. 9235-9240, 1996.

[74] A. D. Crocker, D. H. Overstreet, and J. M. Crocker, "Hypothyroidism leads to increased dopamine receptor sensitivity and concentration," Pharmacology Biochemistry and Behavior, vol. 24, no. 6, pp. 1593-1597, 1986.

[75] A. D. Crocker and D. H. Overstreet, "Modification of the behavioural effects of haloperidol and of dopamine receptor regulation by altered thyroid status," Psychopharmacology, vol. 82, no. 1-2, pp. 102-106, 1984.
[76] A. Diarra, J. M. Lefauconnier, M. Valens, P. Georges, and D. Gripois, "Tyrosine content, influx and accumulation rate, and catecholamine biosynthesis measured in vivo, in the central nervous system and in peripheral organs of the young rat. Influence of neonatal hypo- and hyperthyroidism," Archives Internationales de Physiologie et de Biochimie, vol. 97, no. 5, pp. 317-332, 1989.

[77] R. Chaube and K. P. Joy, "Thyroid hormone modulation of brain in vivo tyrosine hydroxylase activity and kinetics in the female catfish Heteropneustes fossilis," Journal of Endocrinology, vol. 179, no. 2, pp. 205-215, 2003.

[78] F. V. Shikaeva and G. P. Koreneva, "Functional interrelations of monoamines, thyrotropic hormone and thyroid hormones in hyperprolactinemia," Problemy Endokrinologii, vol. 33, no. 4, pp. 27-30, 1987.

[79] J. R. Magliozzi, A. Gold, and J. N. Laubly, "Effect of oral administration of haloperidol on plasma thyrotropin concentrations in men," Psychoneuroendocrinology, vol. 14, no. 1-2, pp. 125-130, 1989.

[80] S. Kundu, A. Biswas, S. Roy, J. De, M. Pramanik, and A. K. Ray, "Thyroid hormone homeostasis in brain: possible involvement of adrenergic phenomenon in adult rat," Neuroendocrinology, vol. 89, no. 2, pp. 140-151, 2009.

[81] D. W. Woolley and E. Shaw, "A biochemical and pharmacological suggestion about certain mental disorders," Proceedings of the National Academy of Sciences of the United State, vol. 40, no. 4, pp. 228-231, 1954.

[82] H. Y. Meltzer and B. W. Massey, "The role of serotonin receptors in the action of atypical antipsychotic drugs," Current Opinion in Pharmacology, vol. 11, no. 1, pp. 59-67, 2011.

[83] A. Abi-Dargham, "Alterations of serotonin transmission in schizophrenia," International Review of Neurobiology, vol. 78, pp. 133-164, 2007.

[84] J. K. Shin, D. T. Malone, I. T. Crosby, and B. Capuano, "Schizophrenia: a systematic review of the disease state, current therapeutics and their molecular mechanisms of action," Current Medicinal Chemistry, vol. 18, no. 9, pp. 1380-1404, 2011.

[85] A. Abi-Dargham, M. Laruelle, G. K. Aghajanian, D. Charney, and J. Krystal, "The role of serotonin in the pathophysiology and treatment of schizophrenia," Journal of Neuropsychiatry and Clinical Neurosciences, vol. 9, no. 1, pp. 1-17, 1997.

[86] J. R. Strawn, N. N. Ekhator, B. B. D’Souza, and T. D. Geracioti, "Pituitary-thyroid state correlates with central dopaminergic and serotonergic activity in healthy humans," Neuropsychobiology, vol. 49, no. 2, pp. 84-87, 2004.

[87] A. J. Cleare, A. McGregor, and V. O’Keane, "Neuroendocrine evidence for an association between hypothyroidism, reduced central 5-HT activity and depression," Clinical Endocrinology, vol. 43, no. 6, pp. 713-719, 1995.

[88] A. J. Cleare, A. McGregor, S. M. Chambers, S. Dawling, and V. O'Keane, "Thyroxine replacement increases central 5-hydroxytryptamine activity and reduces depressive symptoms in hypothyroidism," Neuroendocrinology, vol. 64, no. 1, pp. 6569, 1996.

[89] P. W. Gold, F. K. Goodwin, T. Wehr, and R. Rebar, "Pituitary thyrotropin response to thyrotropin-releasing hormone in affective illness: relationship to spinal fluid amine metabolites," American Journal of Psychiatry, vol. 134, no. 9, pp. 1028-1031, 1977.

[90] C. A. Peabody, H. A. Whiteford, and M. D. Warner, "TRH stimulation test and depression," Psychiatry Research, vol. 22, no. 1, pp. 21-28, 1987. 
[91] P. Blier and C. de Montigny, "Current advances and trends in the treatment of depression," Trends in Pharmacological Sciences, vol. 15, no. 7, pp. 220-226, 1994.

[92] J. M. Ito, T. Valcana, and P. S. Timiras, "Effect of hypo- and hyperthyroidism on regional monoamine metabolism in the adult rat brain," Neuroendocrinology, vol. 24, no. 1, pp. 55-64, 1977.

[93] L. Upadhyaya and J. K. Agrawal, "Effect of L-thyroxine and carbimazole on brain biogenic amines and amino acids in rats," Endocrine Research, vol. 19, no. 2-3, pp. 87-99, 1993.

[94] J. H. Jacoby, G. Mueller, and R. J. Wurtman, "Thyroid state and brain monoamine metabolism," Endocrinology, vol. 97, no. 5, pp. 1332-1335, 1975.

[95] S. M. Tejani-Butt, J. Yang, and A. Kaviani, "Time course of altered thyroid states on 5-HT(1A) receptors and 5-HT uptake sites in rat brain: an autoradiographic analysis," $\mathrm{Neu}$ roendocrinology, vol. 57, no. 6, pp. 1011-1018, 1993.

[96] A. Kulikov, X. Moreau, and R. Jeanningros, "Effects of experimental hypothyroidism on 5-HT(1A), 5-HT(2A) receptors, 5 -HT uptake sites and tryptophan hydroxylase activity in mature rat brain," Neuroendocrinology, vol. 69, no. 6, pp. 453$459,1999$.

[97] G. A. Mason, S. C. Bondy, and C. B. Nemeroff, "The effects of thyroid state on beta-adrenergic and serotonergic receptors in rat brain," Psychoneuroendocrinology, vol. 12, no. 4, pp. 261-270, 1987.

[98] D. C. Javitt and S. R. Zukin, "Recent advances in the phencyclidine model of schizophrenia," American Journal of Psychiatry, vol. 148, no. 10, pp. 1301-1308, 1991.

[99] D. C. Javitt, "Glutamatergic theories of schizophrenia," Israel Journal of Psychiatry and Related Sciences, vol. 47, no. 1, pp. 4-16, 2010.

[100] A. R. Mohn, R. R. Gainetdinov, M. G. Caron, and B. H. Koller, "Mice with reduced NMDA receptor expression display behaviors related to schizophrenia," Cell, vol. 98 , no. 4, pp. 427-436, 1999.

[101] M. C. Arufe, R. Duran, D. Perez-Vences, and M. Alfonso, "Endogenous excitatory amino acid neurotransmission regulates thyroid-stimulating hormone and thyroid hormone secretion in conscious freely moving male rats," Endocrine, vol. 17, no. 3, pp. 193-197, 2002.

[102] P. T. Mannisto, J. Mattila, R. K. Tuominen, and S. Vesalainen, "Effect of some putative amino acid neurotransmitters on the stimulated TSH secretion in male rats," Hormone Research, vol. 17, no. 1, pp. 19-26, 1983.

[103] D. W. Brann, "Glutamate: a major excitatory transmitter in neuroendocrine regulation," Neuroendocrinology, vol. 61, no. 3, pp. 213-225, 1995.

[104] D. A. Lewis, T. Hashimoto, and D. W. Volk, "Cortical inhibitory neurons and schizophrenia," Nature Reviews Neuroscience, vol. 6, no. 4, pp. 312-324, 2005.

[105] S. Akbarian and H. S. Huang, "Molecular and cellular mechanisms of altered GAD1/GAD67 expression in schizophrenia and related disorders," Brain Research Reviews, vol. 52, no. 2, pp. 293-304, 2006.

[106] P. Berbel, P. Marco, J. R. Cerezo, and J. DeFelipe, "Distribution of parvalbumin immunoreactivity in the neocortex of hypothyroid adult rats," Neuroscience Letters, vol. 204, no. 12, pp. 65-68, 1996.

[107] M. Virgili, O. Saverino, M. Vaccari, O. Barnabei, and A. Contestabile, "Temporal, regional and cellular selectivity of neonatal alteration of the thyroid state on neurochemical maturation in the rat," Experimental Brain Research, vol. 83, no. 3, pp. 555-561, 1991.
[108] A. J. Patel, M. Hayashi, and A. Hunt, "Role of thyroid hormone and nerve growth factor in the development of choline acetyltransferase and other cell-specific marker enzymes in the basal forebrain of the rat," Journal of Neurochemistry, vol. 50, no. 3, pp. 803-811, 1988.

[109] P. Honegger and D. Lenoir, "Triiodothyronine enhancement of neuronal differentiation in aggregating fetal rat brain cells cultured in a chemically defined medium," Brain Research, vol. 199, no. 2, pp. 425-434, 1980.

[110] R. Balázs, S. Kovács, P. Teichgräber, W. A. Cocks, and J. T. Eayrs, "Biochemical effects of thyroid deficiency on the developing brain," Journal of Neurochemistry, vol. 15, no. 11, pp. 1335-1349, 1968.

[111] C. A. García Argiz, J. M. Pasquini, B. Kaplún, and C. J. Gómez, "Hormonal regulation of brain development II. Effect of neonatal thyroidectomy on succinate dehydrogenase and other enzymes in developing cerebral cortex and cerebellum of the rat," Brain Research, vol. 6, no. 4, pp. 635-646, 1967.

[112] L. Krawiec, C. A. Garcia Argiz, C. J. Gomez et al., "Hormonal regulation of brain development. 3. Effects of triiodothyronine and growth hormone on the biochemical changes in the cerebral cortex and cerebellum of neonatally thyroidectomized rats," Brain Research, vol. 15, no. 1, pp. 209-218, 1969.

[113] G. Ramírez and C. J. Gómez, "Influence of neonatal hypothyroidism on amino acids in developing rat brain," Journal of Neurochemistry, vol. 13, no. 10, pp. 1017-1025, 1966.

[114] A. Messer, B. Eisenberg, and D. L. Martin, "Effects of mild hyperthyroidism on levels of amino acids in the developing lurcher cerebellum," Journal of Neurogenetics, vol. 5, no. 1, pp. 77-85, 1989.

[115] F. Chapa, B. Kunnecke, R. Calvo, F. E. Del Rey, G. M. De Escobar, and S. Cerdan, "Adult-onset hypothyroidism and the cerebral metabolism of $(1,2-13 \mathrm{C} 2)$ acetate as detected by 13C nuclear magnetic resonance," Endocrinology, vol. 136, no. 1, pp. 296-305, 1995.

[116] H. Hashimoto, C. H. Walker, A. J. Prange Jr., and G. A. Mason, "The effects of thyroid hormones on potassium-stimulated release of $3 \mathrm{H}-\mathrm{GABA}$ by synaptosomes of rat cerebral cortex," Neuropsychopharmacology, vol. 5, no. 1, pp. 49-54, 1991.

[117] J. V. Martin, D. B. Williams, R. M. Fitzgerald, H. K. Im, and P. F. Vonvoigtlander, "Thyroid hormonal modulation of the binding and activity of the $\mathrm{GABA}_{A}$ receptor complex of brain," Neuroscience, vol. 73, no. 3, pp. 705-713, 1996.

[118] R. Chapell, J. Martin, T. K. MacHu, and N. J. Leidenheimer, "Direct channel-gating and modulatory effects of triiodothyronine on recombinant $\mathrm{GABA}_{A}$ receptors," European Journal of Pharmacology, vol. 349, no. 1, pp. 115-121, 1998.

[119] O. M. Ahmed, S. M. Abd El-Tawab, and R. G. Ahmed, "Effects of experimentally induced maternal hypothyroidism and hyperthyroidism on the development of rat offspring: I. The development of the thyroid hormones-neurotransmitters and adenosinergic system interactions," International Journal of Developmental Neuroscience, vol. 28, no. 6, pp. 437-454, 2010.

[120] B. Dean, S. Boer, A. Gibbons, T. Money, and E. Scarr, "Recent advances in postmortem pathology and neurochemistry in schizophrenia," Current Opinion in Psychiatry, vol. 22, no. 2, pp. 154-160, 2009.

[121] S. H. Fatemi, T. D. Folsom, T. J. Reutiman et al., "Abnormal expression of myelination genes and alterations in white matter fractional anisotropy following prenatal viral influenza 
infection at E16 in mice," Schizophrenia Research, vol. 112, no. 1-3, pp. 46-53, 2009.

[122] Y. Hakak, J. R. Walker, C. Li et al., "Genome-wide expression analysis reveals dysregulation of myelination-related genes in chronic schizophrenia," Proceedings of the National Academy of Sciences of the United States of America, vol. 98, no. 8, pp. 4746-4751, 2001.

[123] P. Katsel, K. L. Davis, C. Li et al., "Abnormal indices of cell cycle activity in schizophrenia and their potential association with oligodendrocytes," Neuropsychopharmacology, vol. 33, no. 12, pp. 2993-3009, 2008.

[124] A. Farsetti, B. Desvergne, P. Hallenbeck, J. Robbins, and V. M. Nikodem, "Characterization of myelin basic protein thyroid hormone response element and its function in the context of native and heterologous promoter," Journal of Biological Chemistry, vol. 267, no. 22, pp. 15784-15788, 1992.

[125] N. Ibarrola and A. Rodríguez-Peña, "Hypothyroidism coordinately and transiently affects myelin protein gene expression in most rat brain regions during postnatal development," Brain Research, vol. 752, no. 1-2, pp. 285-293, 1997.

[126] J. C. Dugas, A. Ibrahim, and B. A. Barres, "A crucial role for $\mathrm{p} 57^{\text {Kip } 2}$ in the intracellular timer that controls oligodendrocyte differentiation," Journal of Neuroscience, vol. 27, no. 23, pp. 6185-6196, 2007.

[127] J. C. Dugas, Y. C. Tai, T. P. Speed, J. Ngai, and B. A. Barres, "Functional genomic analysis of oligodendrocyte differentiation," Journal of Neuroscience, vol. 26, no. 43, pp. 1096710983, 2006.

[128] X. Fan, D. C. Goff, and D. C. Henderson, "Inflammation and schizophrenia," Expert Review of Neurotherapeutics, vol. 7, no. 7, pp. 789-796, 2007.

[129] A. Boelen, M. C. Platvoet-Ter Schiphorst, and W. M. Wiersinga, "Association between serum interleukin-6 and serum 3,5,3'-triiodothyronine in nonthyroidal illness," Journal of Clinical Endocrinology and Metabolism, vol. 77, no. 6, pp. 1695-1699, 1993.

[130] A. Boelen, M. C. P. T. Schiphorst, and W. M. Wiersinga, "Soluble cytokine receptors and the low 3,5,3'-triiodothyronine syndrome in patients with nonthyroidal disease," Journal of Clinical Endocrinology and Metabolism, vol. 80, no. 3, pp. 971-976, 1995.

[131] J. Kwakkel, W. M. Wiersinga, and A. Boelen, "Interleukin$1 \beta$ modulates endogenous thyroid hormone receptor $\alpha$ gene transcription in liver cells," Journal of Endocrinology, vol. 194, no. 2, pp. 257-265, 2007.

[132] A. Boelen, J. Kwakkel, A. Alkemade et al., "Induction of type 3 deiodinase activity in inflammatory cells of mice with chronic local inflammation," Endocrinology, vol. 146, no. 12, pp. 5128-5134, 2005.

[133] M. B. Dratman, F. L. Crutchfield, and J. Axelrod, "Localization of triiodothyronine in nerve ending fractions of rat brain," Proceedings of the National Academy of Sciences of the United States of America, vol. 73, no. 3, pp. 941-944, 1976.

[134] C. B. Rozanov and M. B. Dratman, "Immunohistochemical mapping of brain triiodothyronine reveals prominent localization in central noradrenergic systems," Neuroscience, vol. 74, no. 3, pp. 897-915, 1996.

[135] A. G. Trentin, "Thyroid hormone and astrocyte morphogenesis," Journal of Endocrinology, vol. 189, no. 2, pp. 189-197, 2006.

[136] T. S. Scanlan, "Minireview: 3-iodothyronamine (T1AM): a new player on the thyroid endocrine team?" Endocrinology, vol. 150, no. 3, pp. 1108-1111, 2009.
[137] M. B. Dratman and F. L. Crutchfield, "Synaptosomal [125I] triiodothyronine after intravenous [125I]thyroxine," The American Journal of Physiology, vol. 235, no. 6, pp. E638E647, 1978.

[138] A. Kastellakis and T. Valcana, "Characterization of thyroid hormone transport in synaptosomes from rat brain," Molecular and Cellular Endocrinology, vol. 67, no. 2-3, pp. 231-241, 1989.

[139] G. A. Mason, C. H. Walker, and A. J. Prange Jr., "L-triiodothyronine: is this peripheral hormone a central neurotransmitter?" Neuropsychopharmacology, vol. 8, no. 3, pp. 253258, 1993.

[140] T. S. Scanlan, K. L. Suchland, M. E. Hart et al., "3-Iodothyronamine is an endogenous and rapid-acting derivative of thyroid hormone," Nature Medicine, vol. 10, no. 6, pp. 638642, 2004.

[141] R. Zucchi, G. Chiellini, T. S. Scanlan, and D. K. Grandy, "Trace amine-associated receptors and their ligands," British Journal of Pharmacology, vol. 149, no. 8, pp. 967-978, 2006.

[142] M. Eravci, G. Pinna, H. Meinhold, and A. Baumgartner, "Effects of pharmacological and nonpharmacological treatments on thyroid hormone metabolism and concentrations in rat brain," Endocrinology, vol. 141, no. 3, pp. 1027-1040, 2000.

[143] J. de Leon, "Glucuronidation enzymes, genes and psychiatry," International Journal of Neuropsychopharmacology, vol. 6, no. 1, pp. 57-72, 2003.

[144] L. Ng, R. J. Goodyear, C. A. Woods et al., "Hearing loss and retarded cochlear development in mice lacking type 2 iodothyronine deiodinase," Proceedings of the National Academy of Sciences of the United States of America, vol. 101, no. 10, pp. 3474-3479, 2004.

[145] N. Marsh-Armstrong, H. Huang, B. F. Remo, T. T. Liu, and D. D. Brown, "Asymmetric growth and development of the Xenopus laevis retina during metamorphosis is controlled by type III deiodinase," Neuron, vol. 24, no. 4, pp. 871-878, 1999.

[146] E. Holmes, T. M. Tsang, J. T. Huang et al., "Metabolic profiling of csf: evidence that early intervention may impact on disease progression and outcome in schizophrenia," Public Library of Science Medicine, vol. 3, no. 8, article e327, 2006.

[147] E. Schwarz and S. Bahn, "Cerebrospinal fluid: identification of diagnostic markers for schizophrenia," Expert Review of Molecular Diagnostics, vol. 8, no. 2, pp. 209-216, 2008.

[148] S. Sampaolo, A. Campos-Barros, G. Mazziotti et al., "Increased cerebrospinal fluid levels of 3,3',5'- triiodothyronine in patients with Alzheimer's disease," Journal of Clinical Endocrinology and Metabolism, vol. 90, no. 1, pp. 198-202, 2005.

[149] R. Lavado-Autric, E. Ausó, J. V. García-Velasco et al., "Early maternal hypothyroxinemia alters histogenesis and cerebral cortex cytoarchitecture of the progeny," Journal of Clinical Investigation, vol. 111, no. 7, pp. 1073-1082, 2003.

[150] E. Ausó, R. Lavado-Autric, E. Cuevas, F. Escobar Del Rey, G. Morreale De Escobar, and P. Berbel, "A moderate and transient deficiency of maternal thyroid function at the beginning of fetal neocorticogenesis alters neuronal migration," Endocrinology, vol. 145, no. 9, pp. 4037-4047, 2004.

[151] E. Cuevas, E. Ausó, M. Telefont, G. Morreale De Escobar, C. Sotelo, and P. Berbel, "Transient maternal hypothyroxinemia at onset of corticogenesis alters tangential migration of medial ganglionic eminence-derived neurons," European Journal of Neuroscience, vol. 22, no. 3, pp. 541-551, 2005. 
[152] M. J. Costeira, P. Oliveira, N. C. Santos et al., "Psychomotor development of children from an iodine-deficient region," Journal of Pediatrics, vol. 159, no. 3, pp. 447-453, 2011.

[153] G. M. de Escobar, M. J. Obregón, and F. E. Del Rey, "Iodine deficiency and brain development in the first half of pregnancy," Public Health Nutrition A, vol. 10, no. 12, pp. 15541570, 2007.

[154] D. A. Fisher, J. H. Dussault, and T. P. Foley Jr., "Screening for congenital hypothyroidism: results of screening one million North American infants," Journal of Pediatrics, vol. 94, no. 5, pp. 700-705, 1979.

[155] J. F. Rovet, R. M. Ehrlich, and D. L. Sorbara, "Neurodevelopment in infants and preschool children with congenital hypothyroidism: etiological and treatment factors affecting outcome," Journal of Pediatric Psychology, vol. 17, no. 2, pp. 187-213, 1992.

[156] A. J. Rodrigues, P. Leão, J. M. Pêgo et al., "Mechanisms of initiation and reversal of drug-seeking behavior induced by prenatal exposure to glucocorticoids," Molecular Psychiatry. In press.

[157] M. Oliveira, P. Leão, A.-J. Rodrigues, J.-M. Pêgo, J.-J. Cerqueira, and N. Sousa, "Programming effects of antenatal corticosteroids exposure in male sexual behavior," Journal of Sexual Medicine, vol. 8, no. 7, pp. 1965-1974, 2011. 


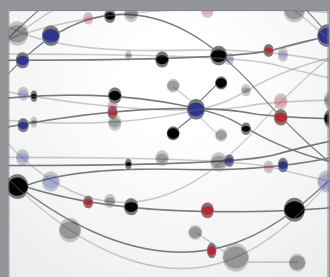

The Scientific World Journal
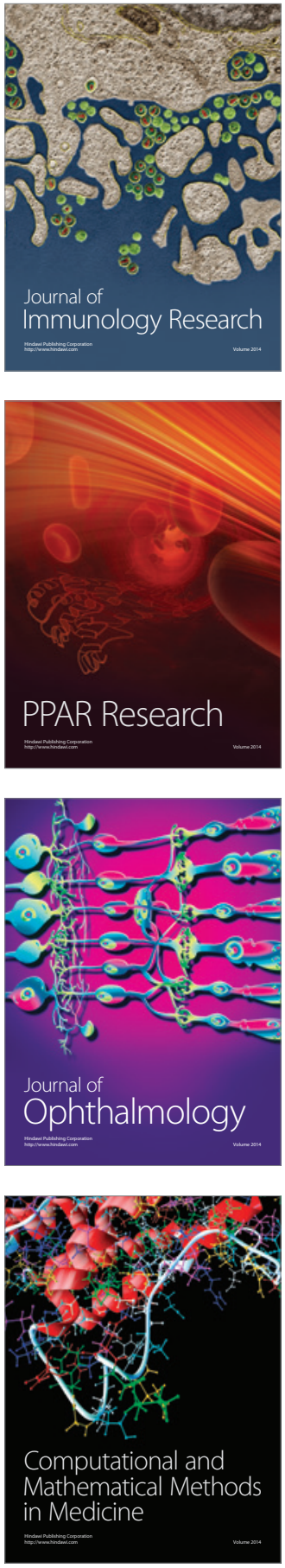

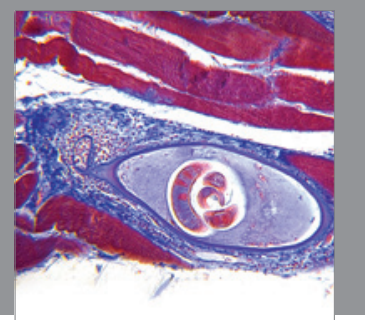

Gastroenterology

Research and Practice
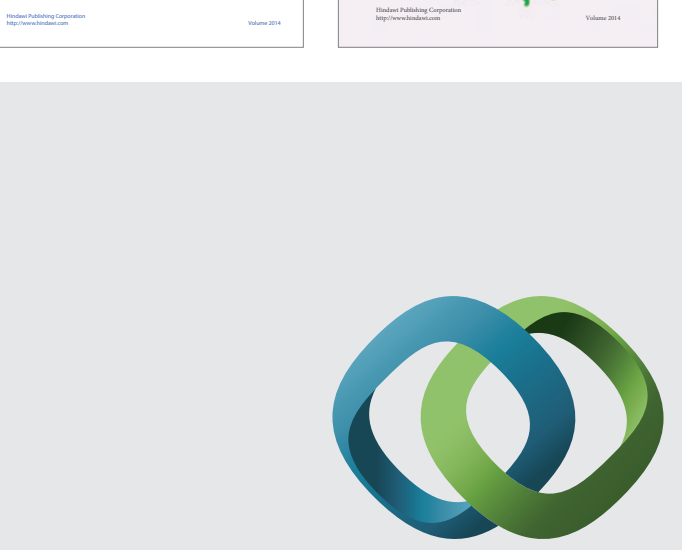

\section{Hindawi}

Submit your manuscripts at

http://www.hindawi.com
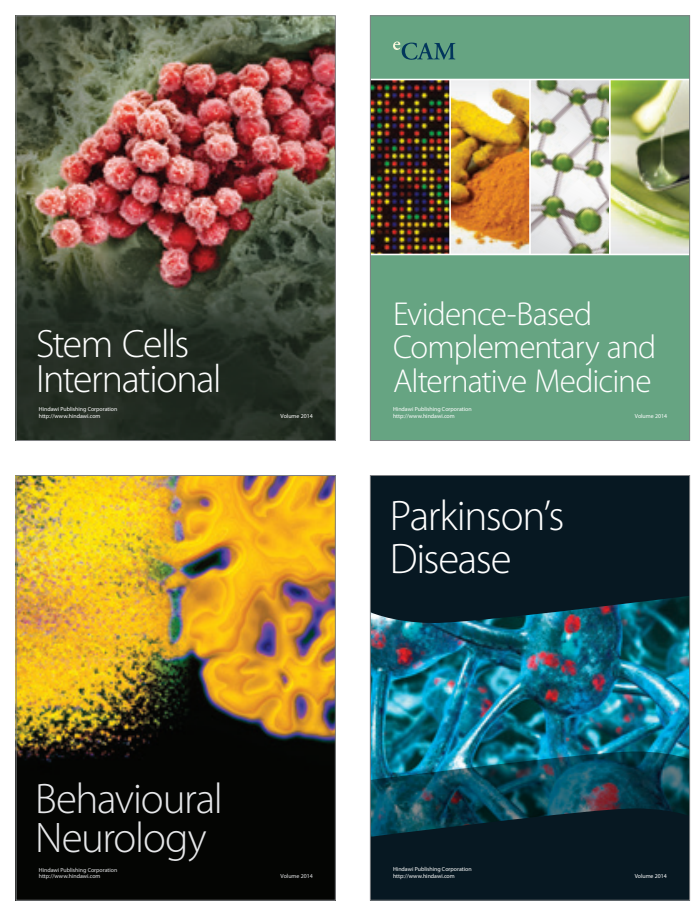

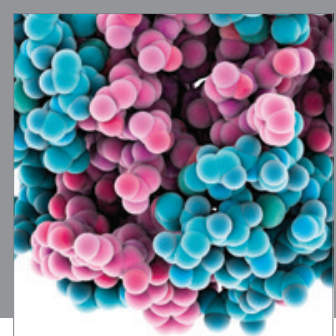

Journal of
Diabetes Research

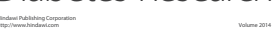

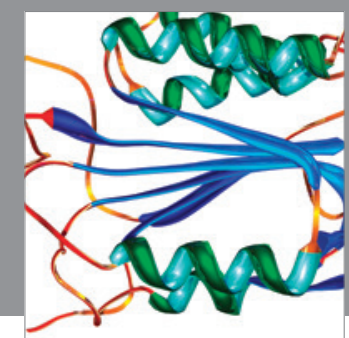

Disease Markers
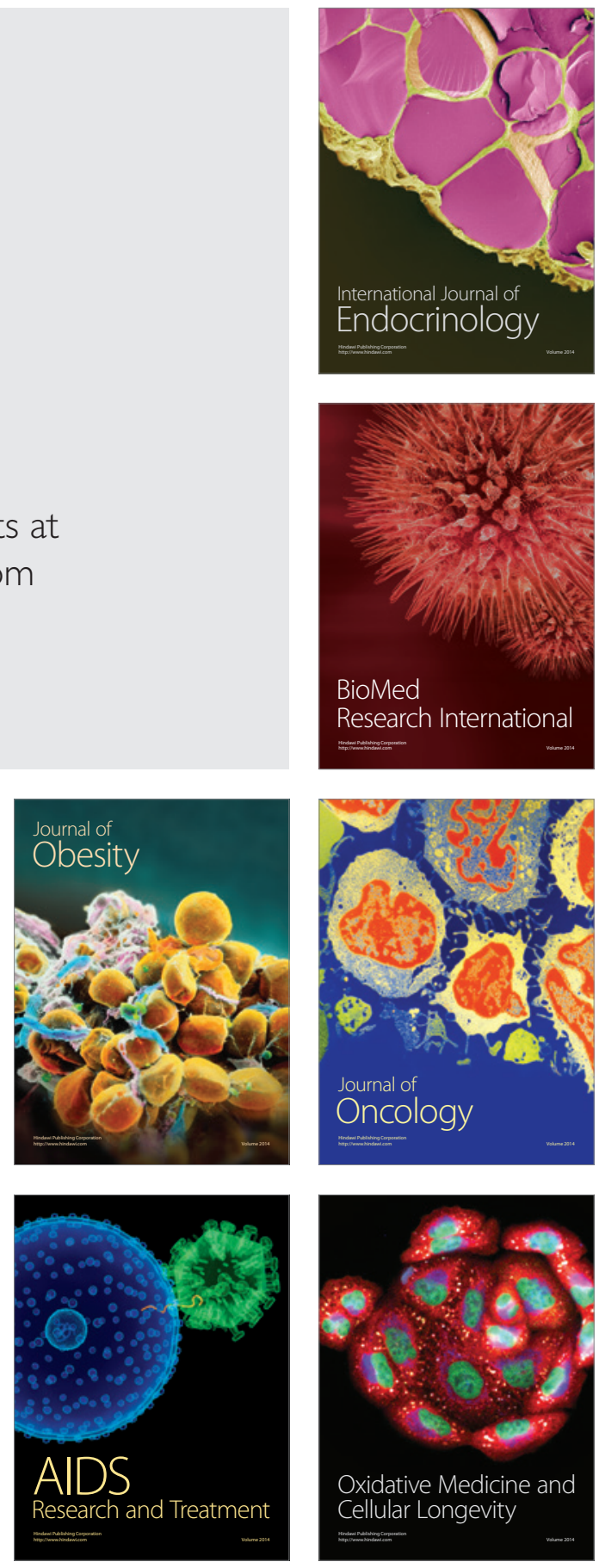